\title{
Successful Treatment of Epidermal Growth Factor Receptor Inhibitor-Induced Periungual Inflammation with Adapalene
}

\author{
Junichi Hachisuka ${ }^{a, b}$ Kazuko Doi ${ }^{a}$ Yoichi Moroi ${ }^{b}$ \\ Masutaka Furue
}

aKaratsu Red Cross Hospital, Karatsu, and bepartment of Dermatology, School of Medical Sciences, Kyushu University, Fukuoka, Japan

\section{Key Words}

Retinoid · Side effects · Anticancer drug

\begin{abstract}
Epidermal growth factor receptor (EGFR) inhibitors are increasingly used for cancer treatment, but commonly carry dermatologic side effects. Periungual inflammation is a particularly painful condition that additionally worsens quality of life. In this paper, we report 3 cases of successful treatment of periungual inflammation induced by 3 different EGFR inhibitors (gefitinib, erlotinib, and cetuximab) with topically applied adapalene.
\end{abstract}

\section{Introduction}

Epidermal growth factor receptor (EGFR) inhibitors are increasingly used as cancer treatment. Skin rashes are a common side effect of EGFR inhibitor and include acneiform skin rash, skin dryness, pruritus, paronychia, hair abnormalities, mucositis, and increased growth of eyelashes and facial hair [1]. Periungual inflammation is a particularly painful condition that additionally worsens quality of life. Therefore, controlling these symptoms is important for patients in order for them to continue treatment. However, treating these eruptions remains challenging as there is no standard treatment. We previously reported that topical application of adapalene was effective in controlling cetuximab-induced periungual inflammation [2]. Here, we report 3 cases of successful treatment of periungual inflammation induced by 3 different EGFR inhibitors (gefitinib, erlotinib, and cetuximab) with topically applied adapalene. 


\section{Case Presentations}

\section{Case 1}

A 77-year-old woman underwent right lower lobectomy for lung cancer 8 years prior. Five years later, pulmonary metastasis was found. She received chemotherapy (carboplatin + gemcitabine, vinorelbine), however, the treatment was ineffective and she was subsequently started on gefitinib. Two months later, painful periungual inflammation of the fingers appeared (fig. 1). The inflamed areas were extremely painful and limited activities of daily living. Pain was considered grade 3 by the Common Terminology Criteria for Adverse Events. A topically applied steroid (betamethasone valerate) was ineffective in relieving the symptoms. We first applied adapalene gel only to the fingers of the left hand. One month later, pain and erythema of the left fingers were notably less than on the right hand. Adapalene gel was subsequently applied to both hands, with continued bilateral improvement in pain and erythema.

\section{Case 2}

A 67-year-old woman was diagnosed with stage IV lung cancer. She initially received chemotherapy (carboplatin + gemcitabine), which was quickly discontinued due to severe anorexia. She was subsequently started on erlotinib. One month later, inflammation of the fingers of the left hand occurred (fig. 2), accompanied by grade 3 pain. The pain was not reduced by topically applied betamethasone valerate. She then started applying adapalene gel to the affected area, with clinically evident reduction in inflammation and resolution of pain within 1 month.

\section{Case 3}

A 72-year-old woman was diagnosed with advanced rectal cancer with lung metastasis. She initially received radiotherapy and chemotherapy (FOLFOX, bevacizumab + FOLFIRI), which failed to stop the cancer from spreading. She was then started on cetuximab and CPT-11. Two months after cetuximab treatment, periungual inflammation appeared on the fingers (fig. 3 ), accompanied by grade 2 pain. Adapalene gel was applied for 2 weeks resulting in reduction of inflammation and pain to grade 1. Discontinuation of cetuximab led to resolution of periungual inflammation.

\section{Discussion}

Members of the human epidermal receptor (HER/ErbB) family, in particular EGFR and HER2/neu/ErbB2, play key roles in the tumorigenic process of epithelial cancers [1, 3]. Blockade of HER signaling can be achieved by monoclonal antibodies directed against the extracellular ligand-binding receptor domain, and by small molecule tyrosine kinase inhibitors, which target the intracellular tyrosine kinase domain [4]. EGFR is overexpressed in malignant tumors, including those of the colon and lung, and plays an important role in cancer proliferation, differentiation, and progression. A majority of human solid tumors express high levels of EGFR, which often correlates with a poor prognosis [5]. Epidermal keratinocytes express EGFR and several of its ligands [6]. EGFR exerts biological effects on epidermal differentiation, keratinocyte migration, and cell survival in the skin [6]. Thus, the wide spectrum of skin toxicities which appear in patients receiving EGFR inhibitors is attributed to a functional disturbance of EGFRmediated homeostasis of normal skin $[1,7]$. Skin toxicities described in patients receiving EGFR inhibitors include acneiform skin rash, skin dryness, pruritus, paronychia, hair abnormality, mucositis, and increased growth of eyelashes and facial hair [1]. Among these, periungual inflammation is an especially disruptive symptom because it leads to 
limitation of activities of daily living. Interestingly, more frequent and severe skin rashes are associated with higher doses of EGFR inhibitors, which in turn are associated with greater tumor response and improved survival [1]. Therefore, controlling skin toxicity of EGFR inhibitors is important for continuing treatment.

The periungual inflammation in our cases resolved with topical application of adapalene. Topical steroid administration was ineffective in 2 cases. We previously reported the successful use of adapalene in cetuximab-induced periungual inflammation [2]. The current study suggests that adapalene seems to be effective for periungual inflammation due to the EGFR tyrosine kinase inhibitors gefitinib and erlotinib.

There is no established evidence-based treatment for the management of EGFR inhibitor-associated skin toxicities, though there are several reports of cases that were effectively treated with retinoids [8-10]. Pomerantz et al. [8] reported that low-dose acitretin was effective for pustular eruptions induced by erlotinib. DeWitt et al. [9] reported that acneiform eruptions due to EGFR inhibitors were reduced by topical adapalene and oral tetracyclines.

All-trans retinoic acid increases the soluble forms of amphiregulin and heparinbinding-EGF [11]. Its effects on keratinocyte proliferation and hyaluronan synthesis are partly mediated through EGFR signaling [12]. In contrast, adapalene is a synthetic retinoid that has selective affinity to RAR- $\beta$ and RAR- $\gamma$ and can affect keratinization and differentiation of epithelial tissue. Adapalene also has anti-inflammatory activity [13]. However, the mechanisms of this anti-inflammatory effect on periungual inflammation remain unclear. While its use appears promising, further studies are needed to clarify the role of adapalene in the treatment of EGFR inhibitor-induced skin eruptions.

\section{Acknowledgments}

This work was partly supported by grants from the Ministry of Education, Culture, Sports, Science and Technology, and the Ministry of Health, Labour and Welfare, Japan.

\section{Disclosure Statement}

There are no conflicts of interest. 


\begin{tabular}{|c|c|c|c|}
\hline $\begin{array}{l}\text { Case Reports in } \\
\text { Dermatology }\end{array}$ & $\begin{array}{l}\text { Case Rep Dermatol 2011;3:130-136 } \\
\text { DOI: } \underline{10.1159 / 000329914}\end{array}$ & $\begin{array}{l}\text { Published online: } \\
\text { June } 30,2011\end{array}$ & $\begin{array}{l}\text { @ } 2011 \text { S. Karger AG, Basel } \\
\text { ISSN } 1662-6567 \\
\text { www.karger.com/cde }\end{array}$ \\
\hline
\end{tabular}

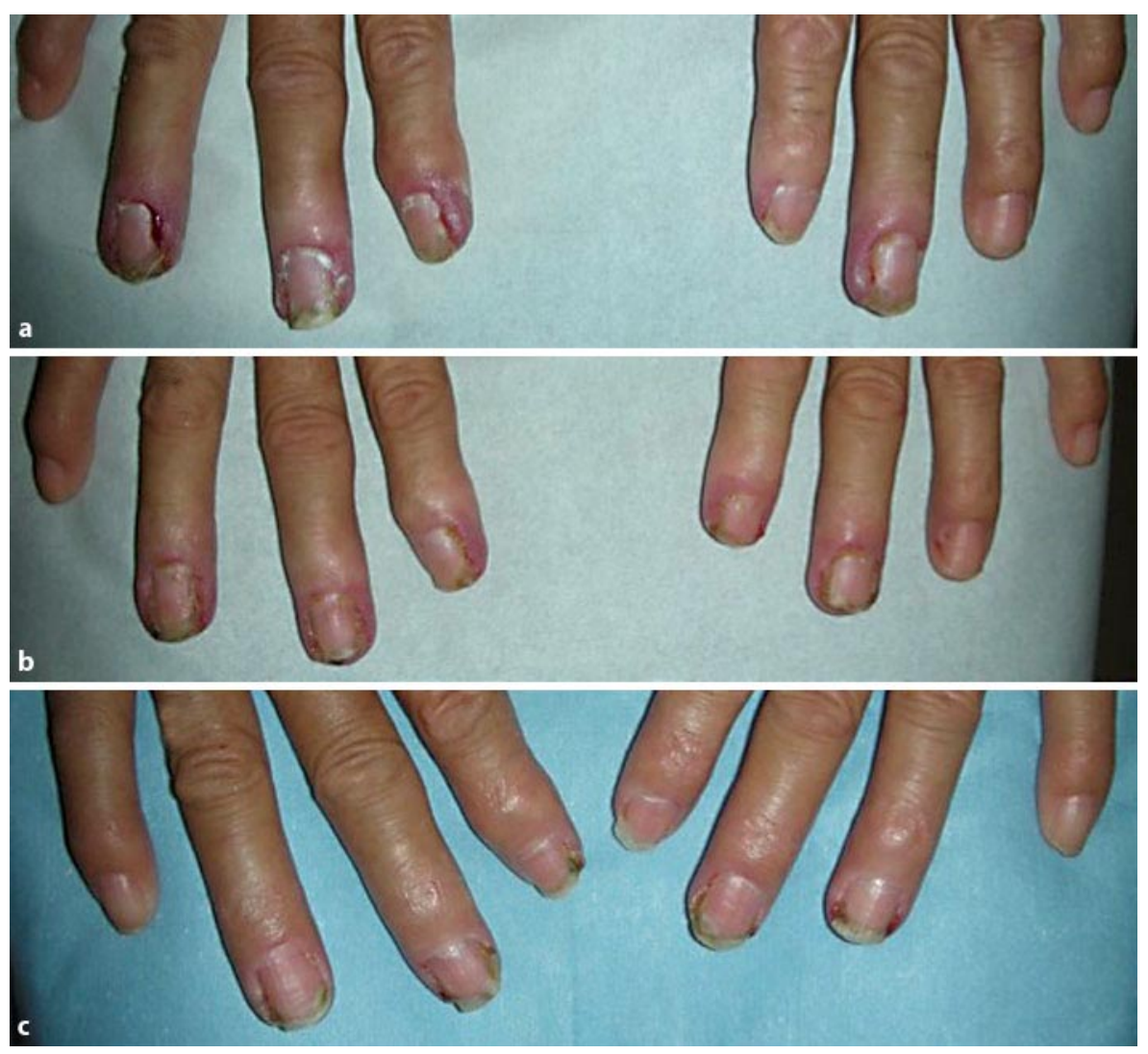

Fig. 1. Case 1: periungual inflammation due to gefitinib. a Before applying adapalene gel.

b One month after applying adapalene gel to the left fingers. c Two month after applying adapalene gel to both hands. 


\begin{tabular}{c|l|l|l}
$\begin{array}{c}\text { Case Reports in } \\
\text { Dermatology }\end{array}$ & $\begin{array}{l}\text { Case Rep Dermatol 2011;3:130-136 } \\
\text { DOI: } 10.1159 / 000329914\end{array}$ & $\begin{array}{l}\text { Published online: } \\
\text { June 30, 2011 }\end{array}$ & $\begin{array}{l}\text { ISN } 2011 \text { S. Karger AG, Basel } \\
\text { ISS 1662-6567 } \\
\text { www.karger.com/cde }\end{array}$ \\
\hline
\end{tabular}
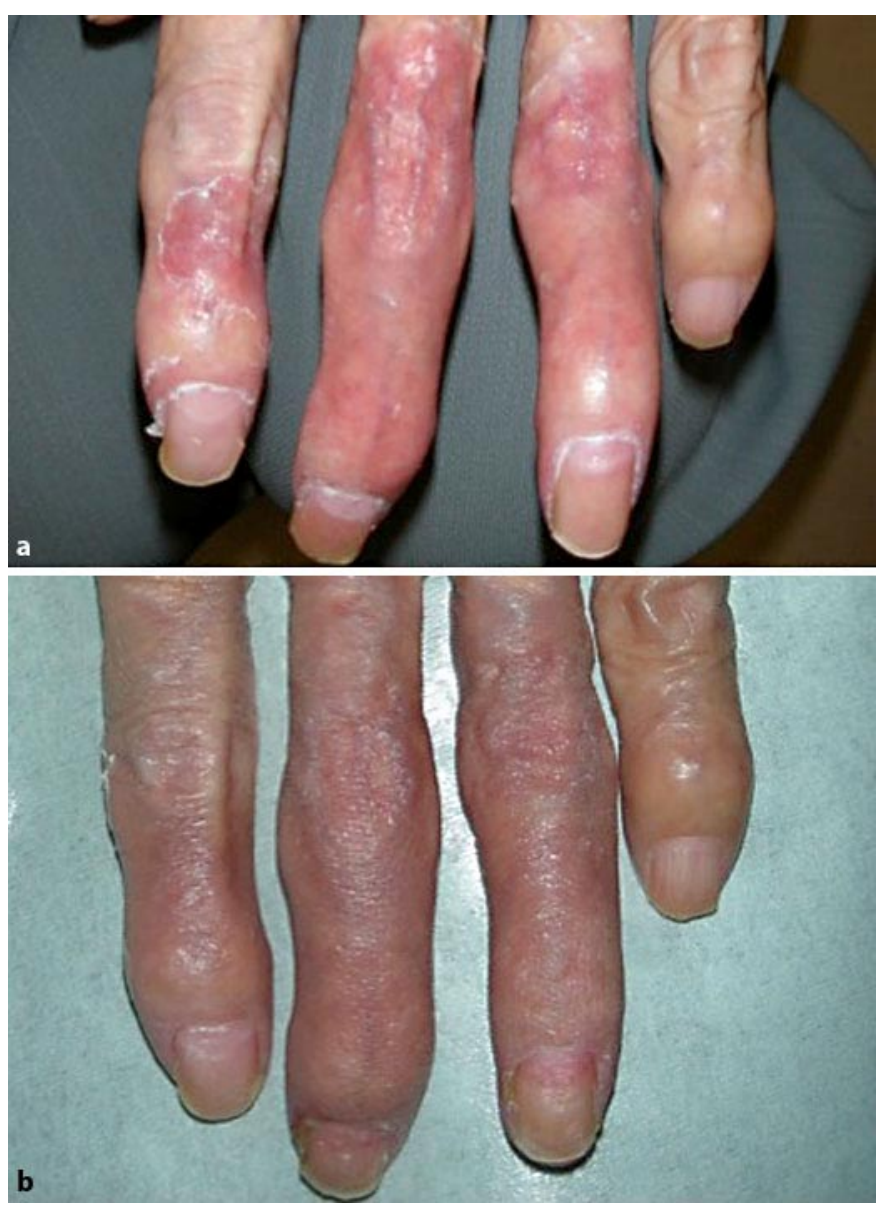

Fig. 2. Case 2: periungual inflammation due to erlotinib. a Before applying adapalene gel. b One month after applying adapalene gel. 


\begin{tabular}{r|l|l|l}
$\begin{array}{c}\text { Case Reports in } \\
\text { Dermatology }\end{array}$ & $\begin{array}{l}\text { Case Rep Dermatol 2011;3:130-136 } \\
\text { DOI: 10.1159/000329914 }\end{array}$ & $\begin{array}{l}\text { Published online: } \\
\text { June 30, 2011 }\end{array}$ & $\begin{array}{l}\text { I 2011 S. Karger AG, Basel } \\
\text { ISSN 1662-6567 } \\
\text { www.karger.com/cde }\end{array}$ \\
\hline
\end{tabular}

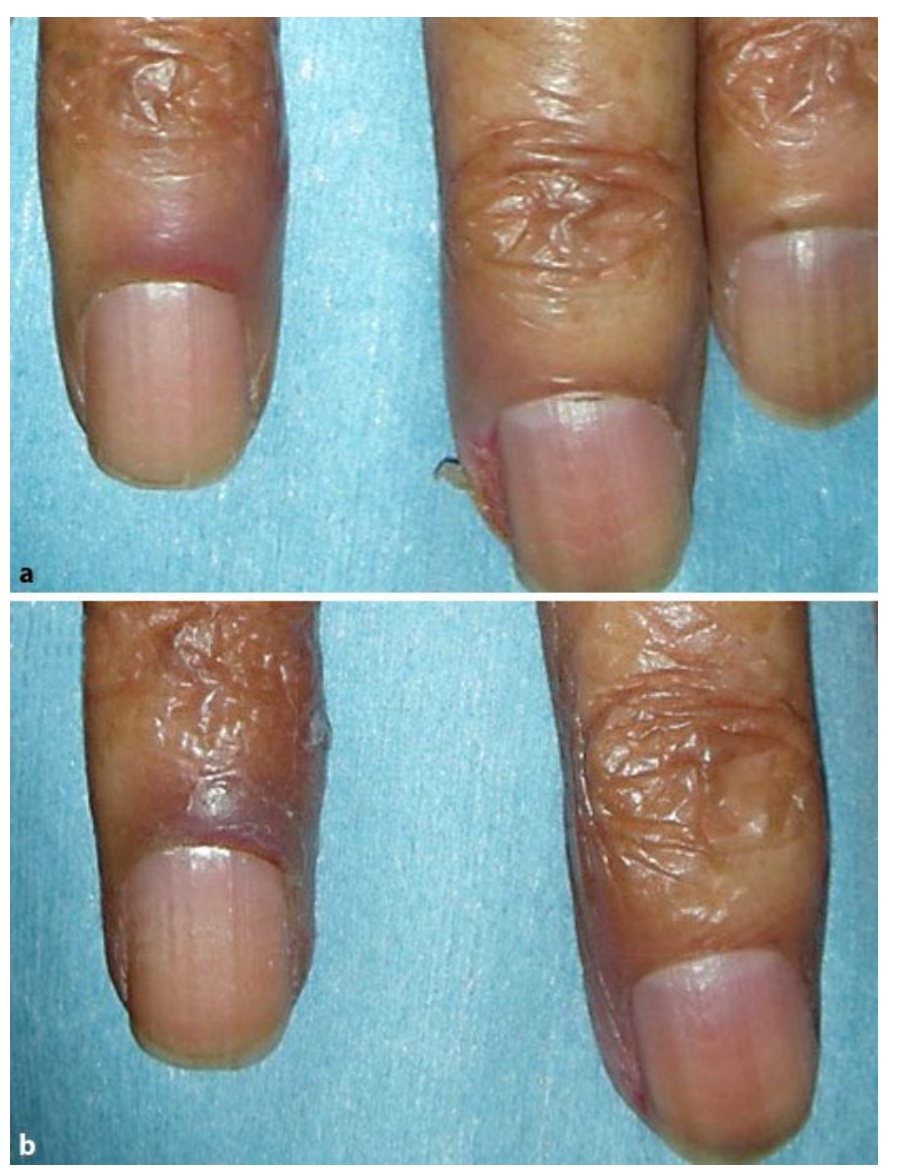

Fig. 3. Case 3: periungual inflammation due to cetuximab. a Before applying adapalene gel. b Two weeks after applying adapalene gel. 


\section{References}

1 Li T, Pérez-Soler R: Skin toxicities associated with epidermal growth factor receptor inhibitors. Targ Oncol 2009;4:107-119.

2 Hachisuka J, Yunotani S, Shidahara S, Moroi Y, Furue M: Effect of adapalene on cetuximab-induced painful periungual inflammation. J Am Acad Dermatol 2011;64:e20-e21.

-3 Laux I, Jain A, Singh S, Agus DB: Epidermal growth factor receptor dimerization status determines skin toxicity to HER-kinase targeted therapies. Br J Cancer 2006;94:85-92.

4 Okines A, Cunningham D, Chau I: Targeting the human EGFR family in esophagogastric cancer. Nat Rev Clin Oncol DOI: $\underline{10.1038 / \text { nrclinonc.2011.45. }}$

5 Salomon DS, Brandt R, Ciardiello F, Normanno N: Epidermal growth factor-related peptides and their receptors in human malignancies. Crit Rev Oncol Hematol 1995;19:183-232.

6 Jost M, Kari C, Rodeck U: The EGF receptor - an essential regulator of multiple epidermal functions. Eur J Dermatol 2000;10:505-510.

7 Lacouture ME: Mechanisms of cutaneous toxicities to EGFR inhibitors. Nat Rev Cancer 2006;10:803-812.

$\checkmark 8$ Pomerantz RG, Chirinos RE, Falo Geskin LJ: Acitretin for treatment of EGFR inhibitor-induced cutaneous toxic effects. Arch Dermatol 2008;144:949-950.

19 DeWitt CA, Siroy AE, Stone SP: Acneiform eruptions associated with epidermal growth factor receptortargeted chemotherapy. J Am Acad Dermatol 2007;56:500-505.

10 Gutzmer R, Werfel T, Mao R, Kapp A, Elsner J: Successful treatment with oral isotretinoin of acneiform skin lesions associated with cetuximab therapy. Br J Dermatol 2005;153:849-851.

11 Rittié L, Varani J, Kang S, Voorhees JJ, Fisher GJ: Retinoid-induced epidermal hyperplasia is mediated by epidermal growth factor receptor activation via specific induction of its ligands heparin-binding EGF and amphiregulin in human skin in vivo. J Invest Dermatol 2006;126:732-739.

12 Pasonen-Seppänen SM, Maytin EV, Törrönen KJ, Hyttinen JM, Hascall VC, MacCallum DK, Kultti AH, Jokela TA, Tammi MI, Tammi RH: All-trans retinoic acid-induced hyaluronan production and hyperplasia are partly mediated by EGFR signaling in epidermal keratinocytes. J Invest Dermatol 2008;128:797-807.

13 Ioannides D, Rigopoulos D, Katsambas A: Topical adapalene gel $0.1 \%$ versus isotretinoin gel $0.05 \%$ in the treatment of acne vulgaris: a randomized open-label clinical trial. Br J Dermatol 2002;147:523-527. 